\title{
A comparative study on reproductive performance and productivity of the Black Bengal and Crossbred goat at Atrai, Bangladesh
}

\author{
Mohammad Mahmudul Hassan ${ }^{1}$, S.M. Niaz Mahmud ${ }^{2}$, S.K.M. Azizul Islam, Omar Faruk Miazi ${ }^{3}$ \\ ${ }^{1}$ Department of Physiology, Biochemistry and Pharmacology, Chittagong Veterinary and Animal Sciences University \\ ${ }^{3}$ Dept. of Genetics and Animal Breeding, Chittagong Veterinary and Animal Sciences University, Khulshi, Chittagong-4202
}

\begin{abstract}
The present investigation was carried out to detect the status of different productive and reproductive parameters of Black Bengal and Crossbred goats at Bandaikhara village under Atrai Upazilla of Naogaon district during the period of September to December/2005. The average age at first sign of heat of Black Bengal goats was better than that of Crossbred goats. In Black Bengal goat the average age at first kidding was $360.5 \pm 10$ days, whereas, in crossbred goats it was $411.5 \pm 15.5$ day. Significantly $(\mathrm{P}<0.01)$ lower the post partum heat period in Black Bengal goat than the crossbred goat. The average kidding interval in Black Bengal and Crossbred goats were $179 \pm 20$ and $270 \pm 22$ days respectively and differences are statistically significant $(\mathrm{P}<0.01)$. The usual numbers of kids at one time in Black Bengal goats vary from single to quadruplet. On the other hand, litter size of crossbred goat was single or twin. The average birth weight of Black Bengal goat was lower than Crossbred goats, which are statistically significant $(\mathrm{P}<0.05)$. The average body weight gain after 365 days is better in Crossbred than Black Bengal goats and statistically significant $(\mathrm{P}<0.01)$. The average milk yield in Crossbred goat was 1.05 liter/day, whereas, in Black Bengal goat, it produces milk that only nourished its kids. It was concluded that the reproductive performance like early maturity, larger litter size, shorter postpartum period, minimum kidding interval are better in Black Bengal goat. On the other hand productive performance like higher birth weight, maximum body weight gain, high milk yield, longer lactation length are suitable in crossbred goat.
\end{abstract}

Key words: Black Bengal goat, Crossbred goat, Production, Reproduction, Performance

\section{Introduction}

Goat is numerically and economically important and promising animal resources in the developing countries especially in Asia and Africa (Hussain, 1999). It is an important source of income for the poor people. Goats are raised by poor farmers and distressed women with little capital investment (FAO, 1991). It is estimated that more than $90 \%$ of goat population comprised of Black Bengal goat (BBGs). Goats rank first position in terms of total livestock population in Bangladesh (FAO, 1999). The total contribution of livestock subsector to the GDP (Gross Domestic Product) is approximately $6.5 \%$ (DLS, 1998). The contribution of livestock sub-sector is $13 \%$ earning of total foreign currency in Bangladesh (Alam, 1993).

Considering the possibilities, a participatory approach in rearing poultry and later goat as a small scale subsistent family enterprise has been promoted by the government and various non-government organizations with the credit and input support since 1980's in this country (Islam et al. 1992; DLS 1998; Fattah, 1999; Das, 2004). Bangladesh Government has also given special emphasis and adopted a national programme on Black Bengal goats for poor farmers to reduce poverty with targeting the Millennium Development Goals (MDGs) achievement since 2003 (Kader, 2006). For rearing goats, a minimum investment of money is often required, even without specific arrangement of housing. Goat graze on barren and road-side land with grass and least home made supplies such as rice gruel, boiled rice, vegetables peels etc. In addition goats fed on jackfruit leaves, which often are available in most of the rearing areas. The higher demands for meat and especially for skin in the local as well as foreign markets focused the goat enterprise extremely prominent to the vulnerable group of people and the existing socio-economic condition of the country. Goat also have important role in generating employment, income, capital storage and improving household nutrition (Devendra, 1992; Hussain, 1999). It has been anticipated that over the next decade, there will be a massive increase in the demand for food of animal origin (100 million tons of meat and 201 million tons of milk), as a result of global population growth, an extra 2.5 billion people to feed by 2020 (DFID, 2000). The normal requirement of animal protein for a man is about 62.5 per day, while people of our country get only 6.90 meats per day (Jabber, 1985).

The importance of goat is strongly emphasized for their versatile production profile and valuable contribution like meat, milk, industrial raw product such as skin, fiber and manure. Black Bengal goats are known to be famous for its adaptability, fertility, prolificacy, meat and skin quality. The present study was therefore undertaken to asses the reproductive performance and productivity of BBGs and the available crossbred goat (CBGs).

\section{Materials and Methods}

The data for reproductive performance such as age of puberty (days), age at insemination, age at first kidding 
(days), ), litter size (number), post partum heat period (days), kidding interval (days) and productivity such as birth weight $(\mathrm{kg})$, body weight gain $(\mathrm{kg})$, milk production (litre/day), lactation length (days) were taken from the different families (goat keeper) using a pre-structured questionnaire. The study area was selected on a village named Bandaikhara under the Atrai Upazilla in Naogaon District due to large number of goats are raised in this area. A total of 159 inhabitant were included in this study which comprised 718 adult female (doe) goats of which BBGs and CBGs were 662 and 56 respectively and 68 adult male goats of which BBGs and CBGs were 50 and 18 respectively. The research work was conducted from September to December /2005 and the data was collected through direct interviewing method (randomly) from the goats owner.The survey schedule was developed according to the objectives of the study. Survey sheet was prepared to collect the desired information from the goats owner and sheet contains reproductive performance such as age of puberty in days, age at insemination, age at first kidding in days, litter size in number, post partum heat period in days, kidding interval in days and productivity such as birth weight in $\mathrm{kg}$, body weight gain in $\mathrm{kg}$ at 365 days, milk production in litre per-day, lactation length in days.

The obtained information was loaded and stored on to the Excel spread sheet. Then data was analyzed using STATA (Stata Corporation College Station) version 9.0. Different types of birth of kidding and their frequency were expressed in percentage.

\section{Results and Discussion Reproductive performance}

Table 1: Reproductive performances of Black Bengal and Crossbred goats

\begin{tabular}{|l|l|l|}
\hline Parameters & $\begin{array}{l}\text { Black Bengal goat } \\
\text { Mean } \pm \text { SD (n) }\end{array}$ & $\begin{array}{l}\text { Crossbred goat } \\
\text { Mean } \pm \text { SD (n) }\end{array}$ \\
\hline $\begin{array}{l}\text { Age at puberty (Days) } \\
\text { Age at first kidding } \\
\text { (Days) }\end{array}$ & $\begin{array}{l}* 196.5 \pm 5.5(662) \\
* 360.5 \pm 10(662)\end{array}$ & $* 411.5 \pm 15.5(56)$ \\
$\begin{array}{l}\text { Litter size (Number) } \\
\text { Post partum heat } \\
\text { period (Days) }\end{array}$ & $\begin{array}{l}* * 96 \pm 0.75(662) \\
\text { Kidding interval }\end{array}$ & $\begin{array}{l}1.25 \pm .25(56) \\
(662)\end{array}$ \\
$\begin{array}{l}* * 121.75 \pm 10.5 \\
\text { (Days) }\end{array}$ & $* 179 \pm 20(662)$ & $* * 270 \pm 22(56)$ \\
\hline
\end{tabular}

Age at puberty: The average age at first sign of heat of crossbred and Black Bengal goats were 222.5 5.5 and 196.5 \pm .5 days respectively, here the duration was greater in crossbred than Black Bengal goats and statistically significant $(\mathrm{P}<0.05)$. BBGs was reported early (200 days) maturing goats than CBGs (225days) (Banerjee, 2004). Somewhat variation occurs due to various causes like presence of buck in the herd
(Devendra \& Burns, 1983), plan of nutrition, availability of forages and temperature.

Age at first kidding: In Black Bengal goat the average age at first kidding was $360.5 \pm 10$ days whereas in crossbred goats it was $411.5 \pm 15.5$ day. So, reproductive performance of Black Bengal goats was higher than crossbred goats and statistically significant $(\mathrm{P}<0.05)$. This result is agreed with Epstein \& Hertz (1964) which depends on photoperiod, kidding season and nutritional status.

Post partum heat period: The average post partum heat period of Black Bengal and crossbred goats were $38.75 \pm 10.5$ and $121.75 \pm 15$ days respectively and differences are highly significant $(\mathrm{P}<0.01)$. Lower the post partum heat period higher the reproductive performance, so, the reproductive performance of Black Bengal goat was better than crossbred goat. This result is in agreement with the study of Shill et al. (2003).

Kidding interval: The average kidding interval in Black Bengal and Crossbred goats were $179 \pm 20$ and $270 \pm 22$ days respectively and differences are highly significant $(\mathrm{P}<0.01)$. Kidding interval of Black Bengal goat was lower that is the reproductive performance is better in Black Bengal goat than the crossbred goat. This result is in agreement with the study of Shill et al. (2003).

Table 2: Different types of litter size per kidding

\begin{tabular}{|l|c|c|c|c|}
\hline \multirow{2}{*}{$\begin{array}{l}\text { Birth types } \\
\text { (Litter size) }\end{array}$} & \multicolumn{2}{|l|}{ Black Bengal goat } & \multicolumn{2}{l|}{ Crossbred goat } \\
\cline { 2 - 5 } & Frequency (n) & Percentage & Frequency (n) & Percentage \\
\hline Single & 140 & 21.14 & 42 & 75 \\
Twin & 373 & 56.34 & 14 & 25 \\
Triplet & 135 & 20.39 & - & - \\
Quadruplet & 14 & 2.11 & - & - \\
\hline
\end{tabular}

Litter size: The usual number of kids at one time in Black Bengal goats vary from single to quadruplet of which twin were the most frequent $(56.32 \%)$ and quadruplet were the least frequent $(2.11 \%)$ litter size. On the other hand, litter size of crossbred goat was either single $(75 \%)$ or twin (25\%). This result is in agreement with the study of Hussain et al. (1995) and Banerjee (2004).

\section{Productive performance}

Table 3: Productive performances of Black Bengal and Crossbred goat

\begin{tabular}{|l|l|l|}
\hline Parameters & $\begin{array}{l}\text { Black Bengal goat } \\
\text { Mean } \pm \text { SD (n) }\end{array}$ & $\begin{array}{l}\text { Crossbred goat } \\
\text { Mean } \pm \text { SD (n) }\end{array}$ \\
\hline $\begin{array}{l}\text { Birth weight (Kg) } \\
\text { Body weight gain after } \\
\text { 365 days (Kg) }\end{array}$ & $* 1.60 \pm .50(662)$ & $* 1.90 \pm .75(56)$ \\
Milk production & $* *$ Nourished only its & $* * 1.05 \pm .50(56)$ \\
(Liter/day ) & kids (662) & $* 2.5(50)$ \\
$\begin{array}{l}\text { Lactation length } \\
(\text { Days) }\end{array}$ & $* 99.25 \pm 10(662)$ & $* 65.50 \pm 7.5(56)$ \\
$* \mathrm{P}<0.05, * * \mathrm{P}<0.01$ & \\
\hline
\end{tabular}


Birth weight: The average birth weight of Black Bengal goat and Crossbred goats were $1.60 \pm .50$ and $1.90 \pm .75$ respectively and differences are statistically significant $(\mathrm{P}<0.05)$. The birth weight of BBGs and CBGs were $1.5 \mathrm{~kg}$ and $2.0 \mathrm{~kg}$ respectively under traditional farming condition of sub-continent (Banerjee, 2004).

Body weight gain: The average body weight gain after 365 days in Black Bengal and Crossbred goats were $20.25 \pm 2.5$ and $29.50 \pm 3.5 \mathrm{~kg}$ respectively and differences are statistically significant $(\mathrm{P}<0.05)$, which agreed with Banerjee (2004).

Milk production: The average milk production in

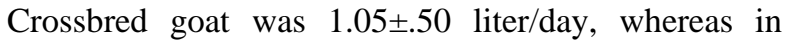
Black Bengal goat, it produces milk that only nourished its kids and differences are highly significant $(\mathrm{P}<0.01)$. This result of milk production is agreed with the result of Hussain et al. (1995) and Banerjee (2004). Due to genetic factor Black Bengal goats yield very poor amount of milk (Payne, 2000).

Lactation Period: Lactation period of Crossbred goats and Black Bengal goats were $99.25 \pm 10$ and $65.50 \pm 7.5$ days respectively and differences are statistically significant $(\mathrm{P}<0.05)$. This result is agreed with the result of Shill et al. (2003).

Acknowledgments: Guidance, help and co-operation received from many persons during the tenure of this research are gratefully acknowledged. The author would like to express special thanks to cowboy Jewel for his help during the survey. Deep sense of gratitude and thanks to Vice-Chancellor of Chittagong Veterinary and Animal Sciences University, Dr. Nitish Chandra Debnath and to Dr. Md. Ahasanul Haque, Professor, Department of Physiology, Biochemistry and Pharmacology for supervision, scholastic guidance, valuable suggestions and constant encouragement during the entire period of the research work.

\section{References}

Alam, J. 1993. The sector for more investment in Bangladesh. Asian Livestock 7: 77-78.

Banerjee, G.C. 2004. A text book of Animal Husbandry. Oxford \& IBH Publishing Co. Pvt. Ltd. New Delhi. 8th edition; pp: 933-961.

Das, P.M. 2004. Role of Veterinary Sciences in Poverty Reduction and Employment Generation through livestock Production. Keynote paper presented at BVA seminar. EIB Auditorium, 04 May 2004.

Devendra, C. 1992. Studies in the nutrition of the indigenous goat at Malaya and requirement of liveweight gain. Malaysian Agric. J. 46: 98-118.

Devendra, C \& Burns, M. 1983. Goat production in the tropics. Commonwealth Agricultural Bureaux. Slough, U.K.
DFID (Department of Foreign Integrated Development), 2000. Halving World poverty by 2015, economic growth, equity and security. Strategies for achieving the international development targets. DFID strategic paper.

DLS (Department of Livestock Services). 1998. Karma Bikash O KarjaKram. An annual report. Livestock and poultry development activities. Government of Bangladesh, Dhaka.

Epstein, H. \& Hertz, A. 1964. Fertility and birth weights of goats in a subtropical environment. Journal of Agric. Sci. UK 62, 237-244 (ABA 32, 3116).

FAO (Food and Agricultural Organization of the United Nations). 1991. Asian Livestock Monthly Technical Magazine of the FAO Animal Production and Health Commission for Asia and the Pacific (APHCA) 8: 85-87.

FAO (Food and Agricultural Organization of the United Nations). 1999. Production Year Book. Rome, Italy 53: 213-219.

Fattah,K.A.1999. Poultry as a tool in poverty eradication and promotion of gender equity. Proceeding of the workshop, March 22-26, organized by the Danish Agricultural and Rural Development Advisers' Forum. pp:16-28.

Hussain, S.S. 1999. Sustainable genetic improvment of economic traits of Black Bengal goats through selective and cross breeding. BAU Res. Prog. 10: 72-80

Hussain, S.S., Horst, P \& Islam, A.B.M.M. 1995. Effects of different factors on pre-weaning survivality of Black Bengal Kids. Small Ruminant Research 18: 1-5.

Islam, M.R, Asaduzzaman, M.U \& Begum, N.J. 1992. Women's Role in Livestock raising in Bangladesh. Asian livestock. XVII(4): 41-45.

Jabber, M.A. 1985. Bangladesh Poshusampad Unnayan Nettio Kowshal. Bangladesh Agricultural Research Council, Dhaka and the Agricultural Development Council, New York, June. pp: 82-83

Kader, M.F. 2006. Khuddra rin pradankari prathistan: Daridra bimusanay pratistanic puji. The Daily Prothom Alo, February 5.

Payne, W.J.A. 2000. Milk production of goat in temperate region. Blackwell Science, Oxford, UK. pp: 12-25.

Shill, B.K., Chowdhury, S.A. \& Hossain, S.M.J. 2003. Chagol Palon Manual: Bangladesh Livestock Research Institute. 2nd edition; pp: 5-7; 150.

Manuscript received on 20.09.07, accepted on 29.11.07 